\title{
Expression and Role of the BDNF Receptor-TrkB in Rat Adrenal Gland under Acute Immobilization Stress
}

\author{
Yusuke Kondo ${ }^{* 1,3}$, Juri Saruta ${ }^{* 1,2,3}$, Masahiro To ${ }^{1,3}$, Naoto Shiiki ${ }^{1,3}$, Chikatoshi Sato ${ }^{1,3}$ \\ and Keiichi Tsukinoki ${ }^{1,3}$
}

${ }^{1}$ Department of Oral Pathology, Kanagawa Dental College Postgraduate School, Japan, ${ }^{2}$ Department of Craniofacial Growth and
Development Dentistry, Division of Orthodontics, Kanagawa Dental College, Japan and ${ }^{3}$ Research Institute of Salivary Gland and
Health Medicine, Kanagawa Dental College, Japan

Received September 9, 2010; accepted October 20, 2010; published online December 3, 2010

\begin{abstract}
We reported that plasma brain-derived neurotrophic factor (BDNF) was maximally elevated following a 60-min period of acute immobilization stress and that salivary glands were the main source of plasma BDNF under this stress condition. However, the expression pattern of the BDNF receptor, Tyrosine receptor kinase $B(T r k B)$, under this condition has yet to be determined. We therefore investigated the effect of this stress on the expression level of TrkB in various rat organs using real-time PCR. No significant differences were found between controls and 60 min-stressed rats with respect to TrkB level in various organs. Only adrenal glands showed significantly increased TrkB mRNA levels after 60 min of stress. TrkB mRNA and protein were observed to localize in chromaffin cells. In addition, we investigated whether BDNF-TrkB interaction influences the release of stress hormones from PC12 cells, derived from chromaffin cells. Truncated receptor, TrkB-T1, was identified in PC12 cells using RT-PCR. Exposure of PC12 cells to BDNF induced the release of catecholamine. This BDNF-evoked release was totally blocked by administration of the K252a in which an inhibitor of Trk receptors. Thus, BDNF-TrkB interactions may modulate catecholamine release from adrenal chromaffin cells under acute stress conditions.
\end{abstract}

Key words: acute immobilization stress, adrenal gland, brain-derived neurotrophic factor (BDNF), Tyrosine receptor kinase $B$ (TrkB)

\section{Introduction}

Brain derived neurotrophic factor (BDNF) belongs to the neurotrophin family, which includes nerve growth factor (NGF) as well as neurotrophin-3, -4/5, -6 and 7 [21]. The members of this family exert their actions by binding to two types of cellular membrane receptors named tyrosine receptor kinase family (Trk) and p75 neurotrophic receptor $\left(p 75^{\mathrm{NTR}}\right)[26,30,42]$. Moreover, there are three members of the Trk receptor family, TrkA, TrkB and TrkC, which all

Correspondence to: Keiichi Tsukinoki, D.D.S., Ph.D., Department of Oral Pathology, Kanagawa Dental College Postgraduate School, 82 Inaoka-cho, Yokosuka, Kanagawa 238-8580, Japan.

E-mail: ktsukino@kdcnet.ac.jp

* Kondo Y. and Saruta J. equally contributed to this study. show different affinities for each neurotrophin [3, 8, 9]. For instance, TrkB has a specific affinity for BDNF [3]. In rodents, alternative splicing of the mRNA that encodes TrkB generates three distinct receptors: the full-length catalytic receptor (TrkB FL), and two truncated forms, both of which lack the intracellular tyrosine kinase domain (TrkBT1 and T2) $[23,29,41]$.

A high level of BDNF expression has been observed in the central nervous system [4]. BDNF plays important roles in the survival, differentiation, maintenance, and protection from insults of neural cells $[4,16]$. In the hippocampus, BDNF has been shown to have an essential role in long-term potentiation [11, 13, 19], and BDNF methionine (met) allele of human subject is associated with poorer episodic memory causing abnormal hippocampal activation [12]. BDNF is also expressed in peripheral tissues such as lachrymal 
glands, lymphocytes, macrophages and salivary glands and is widely distributed in systemic organs [1, 22]. Most of the neural effects of BDNF are mediated by binding to its specific high-affinity receptor TrkB, through ligand-induced dimerization, phosphorylation, and activation [4]. However, the role of BDNF in peripheral tissues is not as well understood.

In a previous ELISA analysis of human serum, Radka et al. reported that serum BDNF values exceed $2.5 \mathrm{ng} / \mathrm{ml}$, and that plasma BDNF levels are approximately $50 \mathrm{pg} / \mathrm{mL}$. The mean BDNF value of rat serum is approximately 1 $\mathrm{ng} / \mathrm{mL}$, while the mean plasma level of BDNF is approximately $150 \mathrm{pg} / \mathrm{mL}$ [28]. The BDNF ELISA signal has little or no level in either the serum or the plasma of mice [28]. Interestingly, low blood BDNF levels have been reported in both schizophrenic patients and in patients with depressive disorders [17]. A recent study of patients affected by major depression reported that low plasma BDNF levels may be a biological marker of suicidal depression [17]. Free BDNF in plasma is assumed to indicate protection or maintenance of the neural cells that mediate TrkB activation [40], since BDNF is able to pass through the blood-brain barrier [27].

Our previous studies have shown that rat salivary glands increase their expression of BDNF under acute stress conditions [39]. Furthermore, the plasma level of BDNF is increased by acute immobilization stress, and submandibular gland production of BDNF contributes to this increase [40]. Indeed, the salivary glands are considered to be a primary source of plasma BDNF, and plasma BDNF concentration is greater in intact rats than in sialoadenectomized rats [40]. These results suggest that BDNF produced by the salivary glands may affect various organs under acute immobilization stress [33]. In particular, maximal augmentation of plasma BDNF level was observed $60 \mathrm{~min}$ after immobilization stress exposure and was accompanied by an increase in BDNF protein expression of the submandibular gland [40]. However, the expression of TrkB at $60 \mathrm{~min}$ after immobilization stress has not been investigated.

The first experiment of this study therefore analyzed TrkB mRNA expression in systemic organs of a male rat after 60 min of immobilization stress. The only organ that showed increased TrkB expression was the adrenal gland. We next analyzed the pattern of TrkB distribution in the adrenal glands of rats under acute stress conditions using in situ hybridization and immunohistochemical techniques to identify TrkB-expressing cells. Interestingly, we showed that TrkB mRNA and protein was localized in chromaffin cells of the adrenal medulla. In the second part of the study, we investigated whether BDNF-TrkB interaction influences the release of stress hormones from PC12 cells, which are derived from adrenal chromaffin cells. The aim of this part of the study was to determine if BDNF-TrkB interactions of the adrenal medulla influence stress reactions.

\section{Materials and Methods}

\section{Experiment 1 \\ Animals}

Nine-week-old male Sprague-Dawley rats (Japan SLC, Inc., Shizuoka, Japan) were used in this study. They were housed in groups of six animals per cage in a room maintained under standardized light (12:12-hr light-dark cycle) and temperature $\left(22 \pm 3^{\circ} \mathrm{C}\right)$ conditions. The animals had free access to food pellets and tap water. To avoid diurnal variations in TrkB expression, we sacrificed all rats between 07:00 and 11:00.

\section{Experimental procedures}

All experiments were performed using four rats per experimental group. On the first day of each experiment, the animals were immobilized to produce acute stress in accordance with a well-established protocol [39, 40]. Rats were fixed on a wooden board $(18 \times 25 \mathrm{~cm})$ in a supine position by means of a leather belt, after which each of their legs was fixed at an angle of $45^{\circ}$ to the body midline with adhesive tape. The rats were exposed to immobilization stress for $60 \mathrm{~min}$ because this was the time at which the plasma level of BDNF peaked in our previous studies [40]. Following selection of an organ that expresses TrkB mRNA in response to stress, additional exposure times of 30 or 180 min were tested. The experimental protocol used in this study was reviewed and approved by the Committee of Ethics on Animal Experiments of Kanagawa Dental College and was carried out in accordance with the Guidelines for Animal Experimentation of Kanagawa Dental College.

\section{RNA extraction and $c D N A$ synthesis}

Total RNA isolation was performed using the ISOGEN reagent (Nippon Gene Co., Ltd., Toyama, Japan), in accordance with the manufacturer's instructions. RNA concentrations were determined by absorbance readings at $260 \mathrm{~nm}$ using a SmartSpec Plus spectrophotometer. Reverse transcription was performed as outlined in the instruction manual, using a first-strand cDNA synthesis kit (Roche Diagnostics Ltd., Lewes, UK).

\section{Real-time PCR}

Real-time polymerase chain reactions (PCR) were performed using rat tissues and a LightCycler system (Roche) as previously described [34]. The primer sequences used were: TrkB forward 5'-CACACACAGGGCTCCTTA3' and reverse 5'-AGTGGTGGTCTGAGGTTGG-3' (TrkB PCR product: $169 \mathrm{bp}$ ) [20]. The $\beta$-actin primer sequences were: 5'-CCTGTATGCCTCTGGTCGTA-3' (forward) and 5'-CCATCTCTTGCTCGAAGTCT-3' (reverse; PCR product: $260 \mathrm{bp}$ ) [34]. The TrkB amplified region is the extracellular domain (Pan-TrkB). The TrkB gene expression level was expressed in terms of the copy number ratio of TrkB to $\beta$-actin for each sample. 


\section{TrkB in situ hybridization (ISH)}

Complementary RNA (cRNA) probes were produced by in vitro transcription of linearized pGEM-T Easy Vectors (Promega Co., WI, USA). Rat TrkB oligonucleotide primers used were as described above. Digoxigenin (DIG)-11-UTPlabeled single-stranded cRNA probes for rat TrkB were prepared using the DIG labeling kit SP6/T7 (Roche) according to the manufacturer's instructions. Procedures for ISH were as described previously [32]. ISH was performed using $3-\mu \mathrm{m}$ tissue sections. Paraffin sections were digested with 1 $\mu \mathrm{g} / \mathrm{ml}$ proteinase $\mathrm{K}$ for $20 \mathrm{~min}$ at $37^{\circ} \mathrm{C}$. Hybridization was performed at $50^{\circ} \mathrm{C}$ for $17 \mathrm{hr}$ using DIG-11-UTP-labeled single-stranded cRNA probes dissolved in hybridization medium (Wako Pure Chemical Industries, Ltd., Tokyo, Japan). After hybridization, mRNA was detected colorimetrically using a DIG-non-radioactive nucleic acid detection kit (Roche).

\section{Immunohistochemistry (IHC)}

Resected rat tissue samples were fixed in $10 \%$ formalin for $24 \mathrm{hr}$. IHC was performed using $3-\mu \mathrm{m}$ sections. Immunohistochemical analysis was performed using Simple stain MAX-PO, according to the instruction manual (Nichirei Biosciences Inc., Tokyo, Japan). Sections were incubated with anti-TrkB rabbit polyclonal antibody (sc-8316, 1:100, Santa Cruz Biotechnology, Inc., Santa Cruz, CA, USA) for $1 \mathrm{hr}$ at room temperature. Non-immunized rabbit IgG was used instead of primary antibody as a negative control. To determine the specificity of the binding, a competitive assay was also attempted using recombinant TrkB (R\&D Systems, Inc., Minneapolis, MN, USA).

\section{Experiment 2 (PC12-based assays) \\ Cell line and $B D N F / T r k$ inhibitor treatments}

PC12 cells derived from chromaffin cells of the rat adrenal medulla (DS Pharma Biomedical Co., Ltd., Osaka, Japan) were seeded on collagen IV-coated culture dishes (BD Biosciences, San Jose, CA, USA) and were cultured in RPMI1640 (Invitrogen Corp., Carlsbad, CA, USA) supplement with $10 \%$ fetal bovine serum (Thermo Fisher Scientific Inc., Waltham, MA, USA) at $37^{\circ} \mathrm{C}$ under $5 \% \mathrm{CO}_{2}$ [2].

Trk signaling of PC12 cells was blocked by the addi-

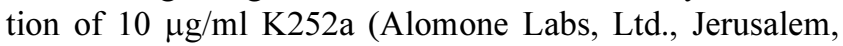
Israel), which is an inhibitor of tyrosine phosphorylation of Trk receptors to the culture medium, for $5 \mathrm{~min}$. The cells were then stimulated with fresh medium containing 100 $\mathrm{ng} / \mathrm{ml}$ recombinant BDNF (rBDNF, R\&D Systems) for 5 min (K252a+rBDNF group). In other experiments, PC 12 cells were stimulated with culture medium containing 10 $\mu \mathrm{g} / \mathrm{ml} \mathrm{K} 252 \mathrm{a}$ (K252a group) or $100 \mathrm{ng} / \mathrm{ml} \mathrm{rBDNF}$ (rBDNF group). For control experiments PC 12 cells were incubated in medium without serum (control group).

\section{Catecholamine assays}

Catecholamines in the medium, such as adrenalin, dopamine and noradrenalin, were analyzed after fractionation by high performance liquid chromatography (HPLC).
The samples were passed through a cation exchange precolumn to remove water soluble materials, and catecholamines were then separated using a HLC-8030 column (Toso Co., Tokyo, Japan). The fluorescence produced by diphenylethylene-diamine and potassium ferricyanide was then measured using an excitation wave length ( $\lambda$ ex) of $355 \mathrm{~nm}$ and an emission wave length $(\lambda \mathrm{em})$ of $470 \mathrm{~nm}$ [31].

\section{RT-PCR of PC12 cells}

RNA extraction and cDNA synthesis protocols are as described above. Reverse transcription-polymerase chain reaction was performed using PC12 cells and TaKaRa Ex Taq (Takara Bio Inc., Shiga, Japan). The primer sequences used to amplify the full-length TrkB receptor (TrkB-FL) were: forward, 5'-TGACGCAGTCGCAGATGCTG-3' and reverse, 5'-TTTCCTGTACATGATGCTCTCTGG-3' (product: 245 bp) (Invitrogen) [7]. The primer sequences for amplification of the truncated TrkB splice variant T1 (TrkBT1) were: forward, 5'-CGGGAGCATCTCTCGGTCT-3' and reverse, 5'-AGGGGGATCTTATGAAACAAA-3' (PCR product: $128 \mathrm{bp}$ ) (Invitrogen) [23]. The primers used to detect the internal control marker GAPDH were: 5'-CCTTCATT GACCTCAACTAC-3' (forward) and 5'-TTCACACCCAT CACAAAC-3' (reverse PCR product: 306 bp) (Invitrogen). The PCR and cycling conditions were: $94^{\circ} \mathrm{C}$ for $10 \mathrm{~min}$ followed by 25 cycles of $94^{\circ} \mathrm{C}$ for $45 \mathrm{sec}, 58^{\circ} \mathrm{C}$ for $30 \mathrm{sec}$ and $72^{\circ} \mathrm{C}$ for $45 \mathrm{sec}$ for TrkB-FL [7]; and $94^{\circ} \mathrm{C}$ for $2 \mathrm{~min}$ followed by 40 cycles of $94^{\circ} \mathrm{C}$ for $15 \mathrm{sec}, 60^{\circ} \mathrm{C}$ for $30 \mathrm{sec}$ and $68^{\circ} \mathrm{C}$ for $30 \mathrm{sec}$ for TrkB-T1 [23], and $98^{\circ} \mathrm{C}$ for $10 \mathrm{sec}$, $55^{\circ} \mathrm{C}$ for $30 \mathrm{sec}$, and $72^{\circ} \mathrm{C}$ for $1 \mathrm{~min}$ for 25 cycles for GAPDH. PCR products were resolved by electrophoresis in $3 \%$ agarose gels, stained with ethidium bromide, and photographed using LAS3000 (Fuji Film Co., Tokyo, Japan).

\section{Immunocytochemistry}

PC12 cells were incubated with medium containing recombinant $\mathrm{BDNF}(100 \mathrm{ng} / \mathrm{ml})$ for $5 \mathrm{~min}$ at $37^{\circ} \mathrm{C}$. The PC12 cells were then fixed with $4 \%$ paraformaldehyde for $5 \mathrm{~min}$ and air-dried. The cells were blocked in $10 \%$ rabbit serum for $30 \mathrm{~min}$ at room temperature. These cells were next incubated with anti-dopamine rabbit polyclonal antibody (sc-11365, 1:50, Santa Cruz) or anti-noradrenalin rabbit polyclonal antibody (ab8887, 1:50, Abcam, Cambridge, MA, USA) in PBS for $1 \mathrm{hr}$ at room temperature. After three washes with PBS (5 min each), the cells were incubated in PBS with polyclonal swine anti-rabbit immunoglobulins/ FITC (Dako Denmark A/S., Glostrup, Denmark) at a dilution of 1:100 for $1 \mathrm{hr}$ at room temperature [37]. Immunofluorescent signals were detected using Biozero BZ-8000 (Keyence Co., Osaka, Japan).

\section{Statistical analysis}

Statistical analyses were carried out using SPSS Version 17.0 (SPSS, Inc., Chicago, IL, USA) and IGOR Pro 6 (Wavemetrics, Lake Oswego, OR, USA) statistics programs. The Mann-Whitney U test was used for quantitative 
analysis of TrkB mRNA in various organs (expressed as mean \pm SD) using SPSS. TrkB mRNA levels in adrenal glands following immobilization stress were analyzed by the Kruskal-Wallis test and, if significant, by the Nemenyi test using IGOR Pro 6. Dopamine and noradrenalin that were degranulated from PC12 cells were analyzed using the Kruskal-Wallis test and, if significant, by multiple comparisons using the Mann-Whitney $U$ test and SPSS. P values $<0.05$ were considered statistically significant.

\section{Results}

Quantitative analysis of TrkB $m R N A$ in various rat organs

TrkB mRNA levels in rat organs were assayed using real time-PCR. We first confirmed that the PCR product thus obtained was TrkB mRNA. Melting curve analysis of the RT-PCR product revealed a single fluorescent peak representing the $T_{m}(A Q)$ of TrkB mRNA in all samples, except for the negative sample (data not shown). In addition, a single RT-PCR product band was observed following agarose gel electrophoresis (data not shown). TrkB/ $\beta$-actin mRNA ratios were calculated for the cerebral cortex, pituitary gland, hippocampus, lung, stomach, liver, pancreas, adrenal gland, and kidney of control and $60 \mathrm{~min}$ stressed rats. TrkB/ $\beta$-actin ratios at $60 \mathrm{~min}$ and $0 \mathrm{~min}$ (nonstressed) respectively were: $0.600 \pm 0.410$ and $0.630 \pm 0.410$ in the cerebral cortex; $0.374 \pm 0.140$ and $0.331 \pm 0.380$ in the hippocampus; $0.177 \pm 0.075$ and $0.112 \pm 0.042$ in the lung; $0.003 \pm 0.001$ and $0.004 \pm 0.001$ in the stomach; $0.004 \pm 0.002$ and $0.006 \pm 0.002$ in the liver; $0.583 \pm 0.270$ and $0.743 \pm 0.370$ in the pancreas; and $0.005 \pm 5.00 \times 10^{-4}$ and $0.004 \pm 2.00 \times 10^{-4}$ in the kidney. No significant differences in $\operatorname{TrkB} / \beta$-actin ratios were found between control and $60 \mathrm{~min}$-stressed rats in these organs.

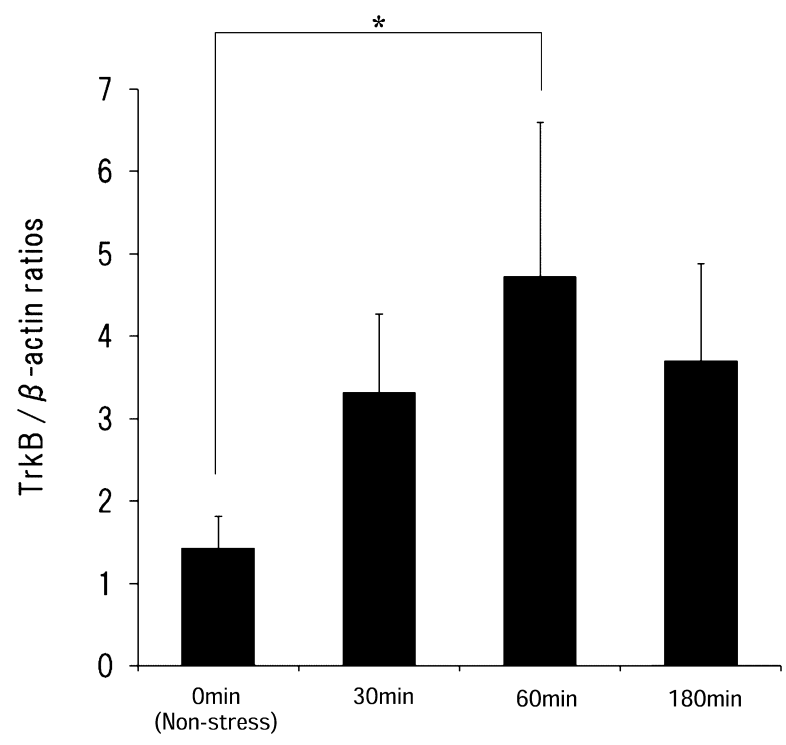

Fig. 1. Analysis of TrkB mRNA levels using real time PCR. TrkB mRNA levels in the adrenal gland of immobilization-stressed rats was assayed using real time PCR. Data are expressed as TrkB/ $\beta$ actin mRNA ratios. TrkB mRNA levels were calculated as: $1.430 \pm 0.390$ for non-stressed rats $(0 \mathrm{~min})$, and $3.330 \pm 0.950$, $4.740 \pm 1.870,3.700 \pm 1.180$ for rats exposed to 30,60 and $180 \mathrm{~min}$, respectively, of immobilization stress ( $\mathrm{n}=6$ for each group, error bars: SEM). There were significant differences between nonstressed and 30-, 60-, or 180-min stressed groups $\left({ }^{*} \mathrm{p}<0.05\right)$.

The respective $60 \mathrm{~min}$ and $0 \mathrm{~min} \mathrm{TrkB} / \beta$-actin ratios were $0.420 \pm 0.090$ and $3.400 \pm 0.740$ in the pituitary gland, and $4.740 \pm 1.870$ and $1.430 \pm 0.390$ in the adrenal gland. In these organs there were significant differences in the TrkB/ $\beta$-actin ratios $(p<0.05)$ between the control groups and the
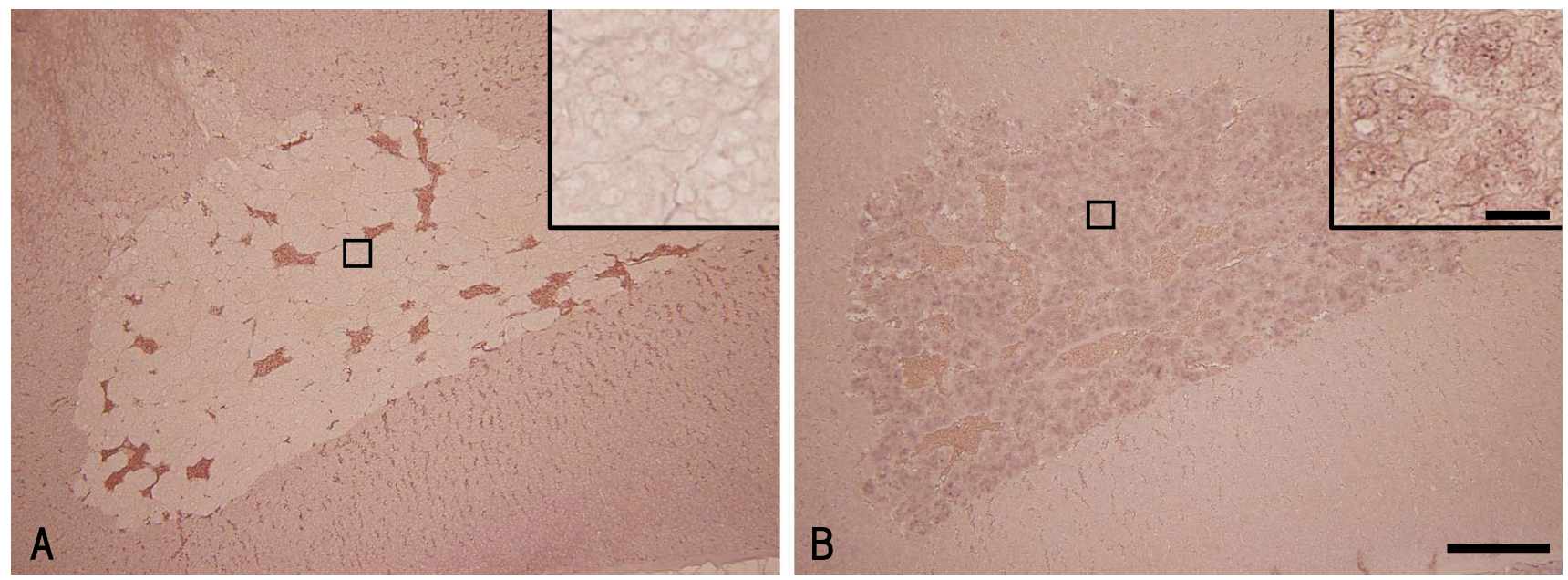

Fig. 2. Localization of TrkB mRNA following immobilization stress. Representative photomicrographs show the expression and localization of TrkB mRNA in paraffin-embedded adrenal tissues from immobilization-stressed rats. TrkB mRNA was detected by in situ hybridization using an antisense TrkB cRNA probe. (A) TrkB mRNA in non-stressed rat adrenal gland. This tissue showed no hybridization signals in adrenal cortex and medulla. (B) TrkB mRNA in 60 min-stressed rat adrenal gland. TrkB mRNA expression was observed in the adrenal medulla. Open square shows inset. $\mathrm{Bar}=200 \mu \mathrm{m}, 20 \mu \mathrm{m}$ (inset). 
60-min immobilization stress groups. However, expression profile of TrkB mRNA in pituitary gland after acute stress has been reported and our results were consistent with a previous report [15].

Therefore, additional experiments were employed in the adrenal gland. When the rats were exposed to immobilization stress for 30,60 , or $180 \mathrm{~min}$, the $\mathrm{TrkB} / \beta$-actin ratios in the adrenal gland were $3.330 \pm 0.950$ at $30 \mathrm{~min}$, $4.740 \pm 1.870$ at $60 \mathrm{~min}$, and $3.700 \pm 1.180$ at $180 \mathrm{~min}$ (Fig. 1). There were significant differences between the $\mathrm{TrkB} / \beta$-actin ratios of controls and of $60 \mathrm{~min}$ in immobilization stress $(p<0.05$ for all comparisons).

\section{TrkB in situ hybridization}

We next analyzed the effect of immobilization stress on TrkB mRNA levels in adrenal using in situ hybridization. A high level of TrkB mRNA expression was detected in positive control rat epididymal cells, but no signals were seen in sections reacted with a sense probe (data not shown).
Little hybridization to the probe was observed in nonstressed adrenal gland tissue, suggesting low, or no TrkB mRNA expression (Fig. 2A). Furthermore, no TrkB mRNA expression was detected in adrenal cortical cells in each of the immobilization stress groups. However, intense TrkB mRNA expression was observed in chromaffin cells of the adrenal medulla after $60 \mathrm{~min}$ immobilization stress (Fig. 2B). Sense probes failed to show hybridization signals in these cells (data not shown). Although erythrocytes showed weak or strong positive-signals, these signals were considered to be non-specific staining.

\section{TrkB immunohistochemistry}

Immunohistochemical analysis of non-stressed adrenal gland tissue revealed little or no expression of TrkB in chromaffin cells of the adrenal medulla (Fig. 3A, asterisk shows adrenal medulla). No TrkB expression was detected in adrenal cortical cells in each of the immobilization stress groups. However, weak TrkB expression was detected in
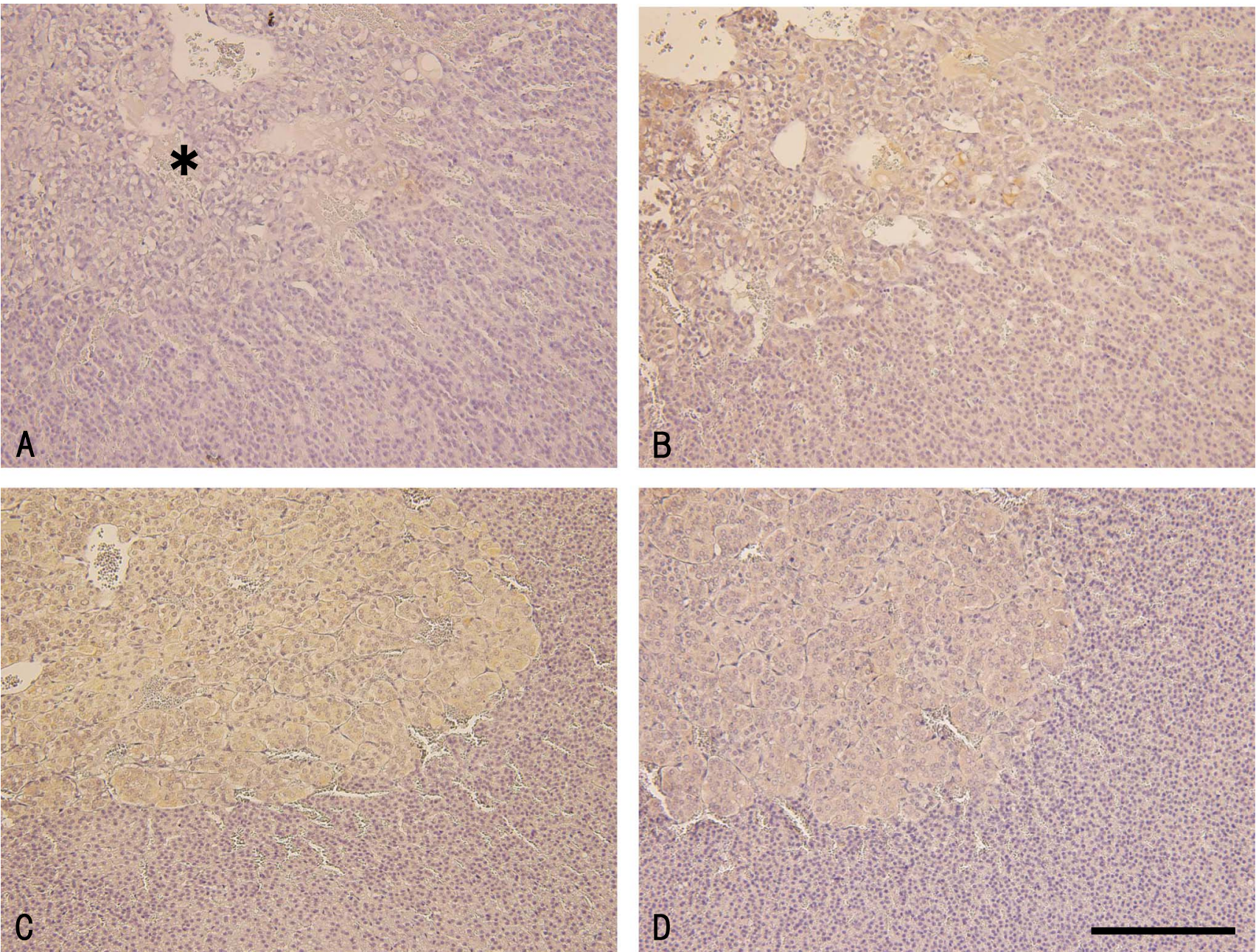

Fig. 3. Immunohistochemical localization of TrkB protein in adrenal tissue following immobilization stress. Representative photomicrographs show the immunohistochemical localization of TrkB protein. (A) TrkB protein levels from non-stressed rat adrenal medulla. (B-D) TrkBexpressing chromaffin cells of the adrenal medulla from the 30-min (B), 60-min (C), and 180-min (D) immobilization-stressed groups. Bar $=100 \mu \mathrm{m}(*$ : adrenal medulla $)$ 
(A)

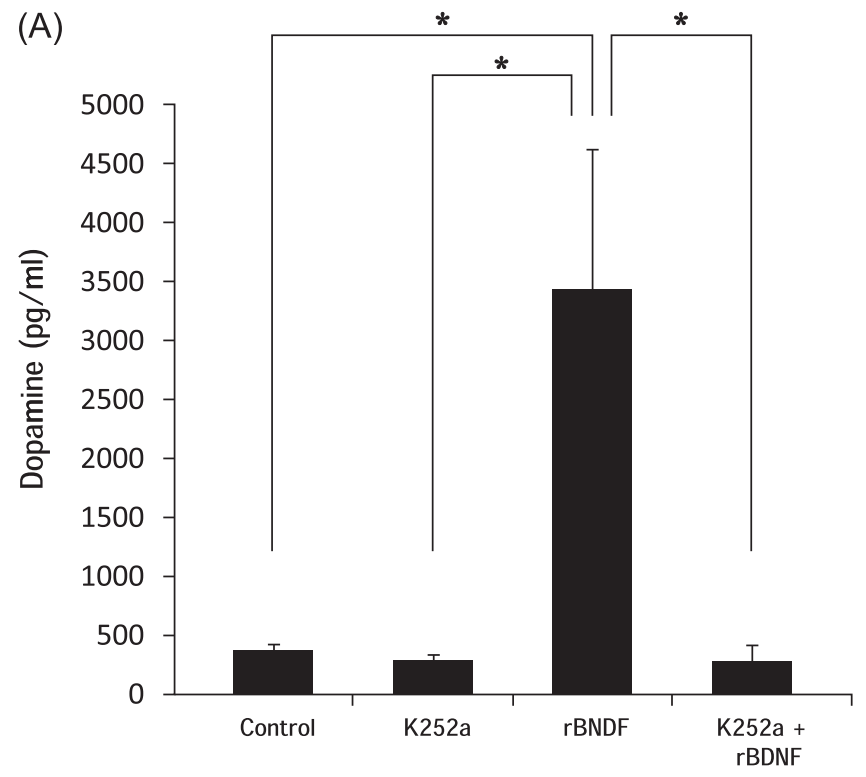

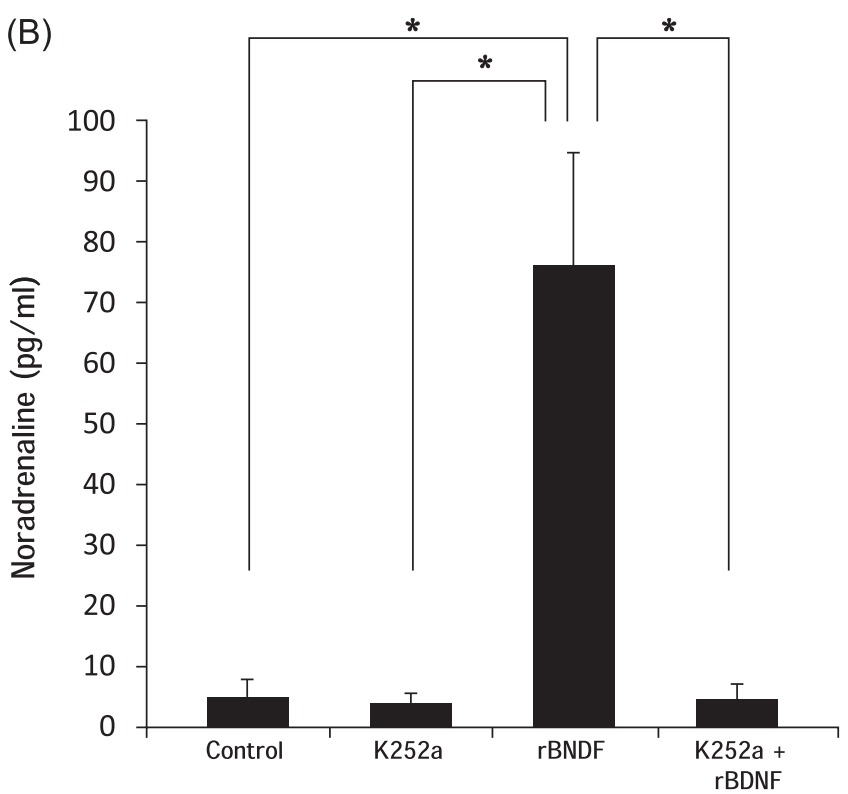

Fig. 4. Effect of BDNF-TrkB signaling on catecholamine secretion from PC12 cells. PC12 cells were treated with recombinant BDNF (rBDNF) and/or the Trk inhibitor, K252a. The levels of dopamine (A) and adrenaline (B) in the media were then assayed using a fluorescent assay following their purification from the media. Dopamine levels were $2.96 \times 10^{2} \pm 0.39 \times 10^{2} \mathrm{pg} / \mathrm{ml}$ in the $\mathrm{K} 252 \mathrm{a}, 3.44 \times 10^{3} \pm 1.18 \times 10^{3} \mathrm{pg} / \mathrm{ml}$ in the $\mathrm{rBDNF}$ and $2.83 \times 10^{2} \pm 1.22 \times 10^{2} \mathrm{pg} / \mathrm{ml}$ in the $\mathrm{K} 252 \mathrm{a}+\mathrm{rBDNF}$ groups and were $3.80 \times 10^{2} \pm 1.02 \times 10^{2} \mathrm{pg} / \mathrm{ml}$ in the control non-treated group (error bars, SD). Noradrenaline levels were $4.00 \pm 1.58 \mathrm{pg} / \mathrm{ml}$ in the K252a, $76.4 \pm 18.4 \mathrm{pg} / \mathrm{ml}$ in the rBDNF and $4.60 \pm 2.30 \mathrm{pg} / \mathrm{ml}$ in the K252a+rBDNF groups, and were $5.00 \pm 2.76 \mathrm{pg} / \mathrm{ml}$ in the control non-treated group (error bars, SD). Significant differences were observed between the dopamine and the noradrenaline levels of the rBDNF group and those of each of the other groups ( $\mathrm{p}<0.05$ for all groups).

chromaffin cells of the adrenal medulla after 30 or $180 \mathrm{~min}$ of immobilization stress (Fig. 3B, D), and strong expression was detected after $60 \mathrm{~min}$ of stress (Fig. 3C). Detection of TrkB expression in stressed adrenal medulla was abolished by competition with recombinant TrkB (data not shown).

\section{Catecholamine levels}

We next investigated if the BDNF-TrkB interaction influences the release of stress hormones from PC12 cells that are derived from adrenal chromaffin cells. The cells were treated with the Trk inhibitor K252a and/or rBDNF and released catecholamines were purified from the media.

Adrenalin was not detected in the media of any experimental group of cells. Dopamine levels of the different groups were: K252a group, $2.96 \times 10^{2} \pm 0.39 \times 10^{2} \mathrm{pg} / \mathrm{ml}$; rBDNF group, $3.44 \times 10^{3} \pm 1.18 \times 10^{3} \mathrm{pg} / \mathrm{ml} ; \mathrm{K} 252 \mathrm{a}+\mathrm{rBDNF}$ group, $2.83 \times 10^{2} \pm 1.22 \times 10^{2} \mathrm{pg} / \mathrm{ml}$ and control group, $3.80 \times 10^{2} \pm 1.02$ $\times 10^{2} \mathrm{pg} / \mathrm{ml}$. There was a significant difference between the dopamine level of the rBDNF group and that of all other groups ( $p<0.05$ for all comparisons). There was no significant different between the levels of the K252a+rBDNF group and those of the control or the K252a group. The dopamine level of the K252a+rBDNF group corresponded to the control level (Fig. 4A). Noradrenalin levels in the media of the different treatment groups were: K252a group, $4.00 \pm 1.58 \mathrm{pg} / \mathrm{ml}$; rBDNF group, $76.4 \pm 18.4 \mathrm{pg} / \mathrm{ml}$; K252a + rBDNF group, $4.60 \pm 2.30 \mathrm{pg} / \mathrm{ml}$ and control group: $5.00 \pm$ $2.76 \mathrm{pg} / \mathrm{ml}$. There was a significant difference between the noradrenalin level of the rBDNF group and that of all other groups ( $\mathrm{p}<0.05$ for all comparisons). There was no significant difference between the K252a+rBDNF group and the control or the K252a group. The noradrenalin level of the $\mathrm{K} 252 \mathrm{a}+\mathrm{rBDNF}$ group corresponded to the control level (Fig. 4B).

\section{RT-PCR analysis of TrkB expression}

We further analyzed TrkB isoform expression in the PC12 cells using RT-PCR. Amplified products corresponding to TrkB-T1 transcripts, but not products corresponding to TrkB-FL, were detected (Fig. 5). An amplified fragment of $306 \mathrm{bp}$, corresponding to a control GAPDH transcript, was detected in both samples.

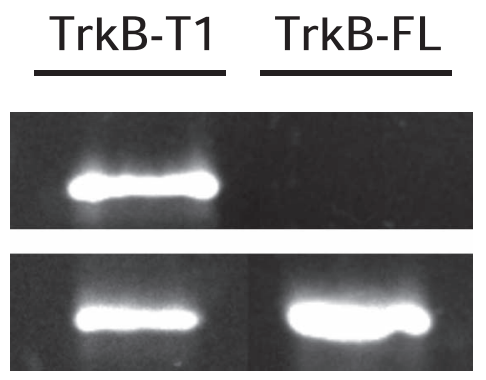

Fig. 5. RT-PCR analysis of the mRNA expression of TrkB isoforms in PC12 cells. RT-PCR analysis detected mRNA expression of the truncated TrkB-T1 isoform in PC12 cells but did not detect TrkBfull length (TrkB-FL) mRNA. GAPDH mRNA was assayed as an internal control. 

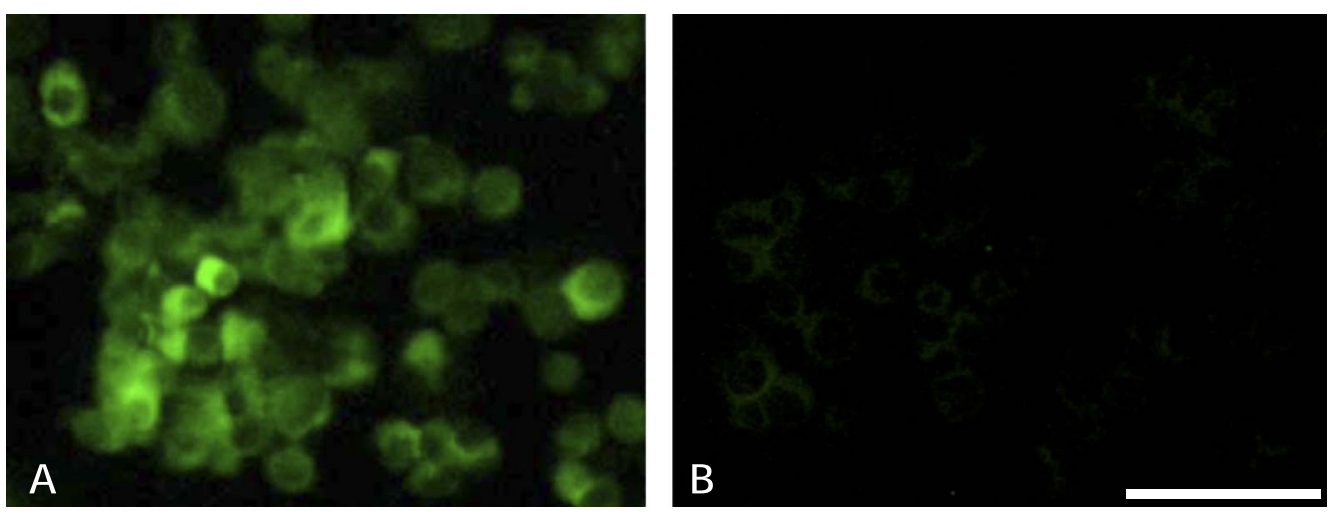

Fig. 6. Immunofluorescence analysis of the effect of BDNF on intracellular dopamine in PC12 cells. PC12 cells were either not treated (A) or were treated (B) with $100 \mathrm{ng}$ of BDNF for $5 \mathrm{~min}$. Intracellular dopamine was then assayed using immunofluorescence. The lack of intracellular dopamine expression in (B) indicated degranulation of the PC12 cells. Bar $=30 \mu \mathrm{m}$.

\section{Immunocytochemistry of catecholamines}

To confirm that the higher catecholamine levels in the media of PC12 cells treated with BDNF, reflected depletion of intracellular catecholamine levels, we assayed intracellular catecholamine levels using immunocytochemistry. PC12 cells were therefore treated with or without BDNF, and were then incubated with anti-dopamine or anti-noradrenalin antibodies, followed by incubation with an FITC-labeled second antibody. In the non-BDNF-stimulated PC12 cells FITC fluorescence, reflecting dopamine (Fig. $6 \mathrm{~A}$ ) or noradrenalin (data not shown) expression, was observed in the cytoplasm, indicating that both of these catecholamines are stored in the cytoplasm of PC12 cells. In contrast, following administration of recombinant BDNF, dopamine positive signals decreased in the cytoplasm (Fig. $6 \mathrm{~B})$, consistent with BDNF-induced release of dopamine into the culture medium of PC12 cells. Although noradrenalin expression patterns were similar to immunocytochemical results of dopamine, noradrenalin signals were lower than those for dopamine (data not shown).

\section{Discussion}

In this paper, the TrkB mRNA level of organs including cerebral cortex, hippocampus, lung, stomach, liver, pancreas, kidney, pituitary gland and adrenal gland were determined by real-time PCR using a primer set that recognizes the TrkB extracellular domain (pan-TrkB). This screening demonstrated that the TrkB mRNA level of cerebral cortex, hippocampus, lung, stomach, liver, pancreas and kidney was not affected by acute immobilization stress for $60 \mathrm{~min}$ whereas the TrkB mRNA expression level of pituitary gland and adrenal gland was modified. Interestingly, the latter two organs are characterized by the production and release of stress hormones. Furthermore, there is an intimate interplay between the pituitary gland and the adrenal gland during stress responses. Immobilization stress is known to up- or down-regulate TrkB expression depending on the time course of the stress, and the area of the brain that is assayed
$[10,15,20,25]$. Our data were consistent with a previous report that TrkB mRNA levels are decreased under immobilization stress conditions in the rat pituitary gland [15]. Givalois et al. suggested a novel physiological role of BDNF as a hormonal factor in the endocrine response of the pituitary gland to stress [15]. In addition, glucocorticoids and other adrenal stress hormones may modulate pituitary functions by regulating the expression of neurotrophic factors and its receptors [18]. Based on these previous reports and our data, it was likely that there are interactions between the pituitary and the adrenal gland that mediate neurotrophic factors in stress conditions.

When the TrkB mRNA expression profile of rat adrenal gland was investigated, the levels of TrkB mRNA were significantly higher after $60 \mathrm{~min}$ of stress than in control (non-stressed) rats, or in rats that were stressed for 30 or 180 min. No significant differences in TrkB mRNA levels were observed between the control and the 30 or 180 minstressed groups. Schober et al. were the first to report that neurotrophin-4, TrkA, and p75 are expressed in rat adrenal medulla chromaffin cells in the absence of stress, but they were unable to detect BDNF, NT-3, TrkB, or TrkC mRNA by in situ hybridization using ${ }^{35} \mathrm{~S}-\mathrm{UTP}$-labeled cRNA probes [35]. BDNF protein expression has been localized to the subcapsular region of the rat adrenal cortex $[36,38]$. In the present paper, using multiple techniques, we demonstrated increased expression of TrkB mRNA and protein in rat adrenal gland tissue following stress. We also determined that TrkB protein and mRNA are localized in chromaffin cells of rat adrenal gland tissue. Our data indicate that TrkB expression in the adrenal medulla following acute stress may be important at $60 \mathrm{~min}$ of stress but not at later times because TrkB mRNA levels had returned to control levels following $180 \mathrm{~min}$ of stress. Indeed, the time of the highest TrkB expression following stress corresponds with the period of time when the level of plasma BDNF is at its highest following stress; i.e., at $60 \mathrm{~min}$ [40]. NGF has previously been reported to exert its physiological role via the adrenal gland following aggressive behavior [1]. Exogenous NGF 
administration results in marked adrenal gland hypertrophy [5] and blood NGF may target the adrenal gland [1]. Since substances produced by the adrenal cortex pass from the cortical artery into the adrenal medulla, BDNF produced by the adrenal cortex may also interact with TrkB expressed on the adrenal medulla. Thus, it is possible that blood BDNF, in a similar manner to blood NGF, activates TrkB of adrenal medulla during acute stress.

BDNF induced the release of catecholamines such as noradrenalin and dopamine from $\mathrm{PC} 12$ cells, and this BDNF-evoked release is completely blocked by the tyrosine kinase inhibitor K252a. PC12 cells are a well established cell line that is derived from adrenal medulla, but no contains the adrenalin [14]. BDNF-evoked release of noradrenalin and dopamine could be explained by TrkB activation. Most dopaminergic cells, including retinal cells, in a wide range of species, express TrkB $[24,36]$. In other areas of the central nervous system, BDNF has been found to induce the release of dopamine [6]. Truncated TrkB receptors have dominant inhibitory effects on BDNF signaling in cultured hippocampal neurons. However, in recent years, it has been shown that the truncated TrkB receptor, TrkB-T1, mediates neurotrophin-evoked calcium signaling in glial cells and plays a direct signaling role in mediating inositol1,4,5-trisphoshate-dependent calcium release [29]. This signaling pathway is consistent with the signaling mechanism that mediates the release of dopamine, which involves an increase in intracellular $\mathrm{Ca}^{2-}$ levels in retinal amacrine cells [24]. Clearly, PC12 cells have TrkB-T1 receptors, which suggest that BDNF may induce the release of dopamine by directly interacting with these receptors. Although PC12 cells do not express adrenalin, we believe that BDNF is likely to play a role in the release of catecholamines, including adrenalin, from adrenal tissue in vivo. We are currently investigating the function of BDNF-TrkB interaction in adrenal medulla under conditions of acute immobilization stress in vivo.

In summary, we present a number of novel findings regarding the role of $\mathrm{BDNF}$ and its receptor TrkB during immobilization stress. First, TrkB receptor expression was increased under conditions of acute stress and was highest at $60 \mathrm{~min}$ following stress in the adrenal medulla while TrkB receptors are expressed under non-stressed conditions, but at a lower level. Second, blood BDNF may activate the TrkB receptors of adrenal medulla during acute stress. Finally, BDNF directly induces the release of catecholamines from PC12 cells by activation of TrkB-T1 receptors. Thus, BDNF-TrkB interactions may modulate catecholamine release from adrenal chromaffin cells under acute stress conditions.

\section{Acknowledgments}

This research was supported in part by a Grant-in Aid for Young Scientists (Start-up, \#1989023), Scientific Research (B, \#20390467).

\section{References}

1. Aloe, L., Alleva, E., Böhm, A. and Levi-Montalcini, R. (1986) Aggressive behavior induces release of nerve growth factor from mouse salivary gland into bloodstream. Proc. Natl. Acad. Sci. US A 83; 6184-6187.

2. Amino, S., Itakura, M., Ohnishi, H., Tsujimura, J., Koizumi, S., Takei, N. and Takahashi, M. (2002) Nerve growth factor enhances neurotransmitter release from $\mathrm{PC} 12$ cells by increasing $\mathrm{Ca}(2+)$-responsible secretory vesicles through the activation of mitogen-activated protein kinase and phosphatidylinositol 3kinase. J. Biochem. 131; 887-894.

3. Barbacid, M. (1994) The Trk family of neurotrophin receptors. J. Neurobiol. 25; 1386-1403.

4. Barde, Y. A. (1989) Trophic factors and neuronal survival. Neuron 2; 1525-1534

5. Bigi, S., Maestripieri, D., Aloe, L. and Alleva, E. (1992) NGF decreases isolation-induced aggressive behavior, while increasing adrenal volume, in adult male mice. Physiol. Behav. 51; 337-343.

6. Blöchl, A. and Sirrenberg, C. (1996) Neurotrophins stimulate the release of dopamine from rat mesencephalic neurons via Trk and p75Lntr receptors. J. Biol. Chem. 271; 21100-21107.

7. Braas, K. M., Schutz, K. C., Bond, J. P., Vizzard, M. A., Girard, B. M. and May, V. (2007) Microarray analyses of pituitary adenylate cyclase activating polypeptide (PACAP)-regulated gene targets in sympathetic neurons. Peptides 28; 1856-1870.

8. Chao, M. V. (1994) The p75 neurotrophin receptor. J. Neurobiol. $25 ; 1373-1385$.

9. Chao, M. V. and Hempstead, B. L. (1995) p75 and Trk: a tworeceptor system. Trends Neurosci. 18; 321-326.

10. Charrier, C., Chigr, F., Tardivel, C., Mahaut, S., Jean, A., Najimi, M. and Moyse, E. (2006) BDNF regulation in the rat dorsal vagal complex during stress-induced anorexia. Brain Res. 1107; 52-57.

11. Dragunow, M., Hughes, P., Mason-Parker, S. E., Lawlor, P. and Abraham, W. C. (1997) TrkB expression in dentate granule cells is associated with a late phase of long-term potentiation. Brain Res. Mol. Brain Res. 46; 274-280.

12. Egan, M. F., Kojima, M., Callicott, J. H., Goldberg, T. E., Kolachana, B. S., Bertolino, A., Zaitsev, E., Gold, B., Goldman, D., Dean, M., Lu, B. and Weinberger, D. R. (2003) The BDNF val66met polymorphism affects activity-dependent secretion of BDNF and human memory and hippocampal function. Cell 112; 257-269.

13. Figurov, A., Pozzo-Miller, L. D., Olafsson, P., Wang, T. and Lu, B. (1996) Regulation of synaptic responses to high-frequency stimulation and LTP by neurotrophins in the hippocampus. Nature 381; 706-709.

14. Fornai, F., Lenzi, P., Capobianco, L., Iacovelli, L., Scarselli, P., Lazzeri, G. and De Blasi, A. (2008) Involvement of dopamine receptors and beta-arrestin in metamphetamine-induced inclusions formation in PC12 cells. J. Neurochem. 105; 1939-1947.

15. Givalois, L., Marimigère, F., Rage, F., Ixart, G., Arancibia, S. and Tapia-Arancibia, L. (2001) Immobilization stress rapidly and differentially modulates BDNF and TrkB mRNA expression in the pituitary gland of adult male rat. Neuroendocrinology 74 ; 148-159.

16. Gunjigake, K. K., Goto, T., Nakao, K., Konoo, T., Kobayashi, S. and Yamaguchi, K. (2006) Correlation between the appearance of neuropeptides in the rat trigeminal ganglion and reinnervation of the healing root socket after tooth extraction. Acta Histochem. Cytochem. 39; 69-77.

17. Karege, F., Perret, G., Bondolfi, G., Schwald, M., Bertschy, G. and Aubry, J. M. (2002) Decreased serum brain-derived neurotrophic factor levels in major depressed patients. Psychiatry Res. 109; $143-148$.

18. Kononen, J., Soinila, S., Persson, H., Honkaniemi, J., Hökfelt, T. and Pelto-Huikko, M. (1994) Neurotrophins and their receptors in 
the rat pituitary gland: regulation of BDNF and trkB mRNA levels by adrenal hormones. Brain Res. Mol. Brain Res. 27; 347354.

19. Korte, M., Staiger, V., Griesbeck, O., Thoenen, H. and Bonhoeffer, T. (1996) The involvement of brain-derived neurotrophic factor in hippocampal long-term potentiation revealed by gene targeting experiments. J. Physiol. (Paris) 90; 157-164.

20. Lee, T., Saruta, J., Sasaguri, K., Sato, S. and Tsukinoki, K. (2008) Allowing animals to bite reverses the effects of immobilization stress on hippocampal neurotrophin expression. Brain Res. 1195; $43-49$

21. Lewin, G. R. and Barde, Y. A. (1996). Physiology of the neurotrophins. Аnпu. Rev. Neurosci. 19; 289-317.

22. Lomen-Hoerth, C. and Schooter, E. M. (1995) Widespread neurotrophin receptor expression in the immune system and other nonneuronal rat tissues. J. Neurochem. 64; 1780-1789.

23. Mizoguchi, Y., Monji, A., Kato, T., Seki, Y., Gotoh, L., Horikawa, H., Suzuki, S. O., Iwaki, T., Yonaha, M., Hashioka, S. and Kanba, S. (2009) Brain-derived neurotrophic factor induces sustained elevation of intracellular $\mathrm{Ca} 2+$ in rodent microglia. J. Immunol. 183; 7778-7786.

24. Neal, M., Cunningham, J., Lever, I., Pezet, S. and Malcangio, M. (2003) Mechanism by which brain-derived neurotrophic factor increases dopamine release from the rabbit retina. Invest. Ophthalmol. Vis. Sci. 44; 791-798.

25. Nibuya, M., Takahashi, M., Russell, D. S. and Duman, R. S. (1999) Repeated stress increases catalytic TrkB mRNA in rat hippocampus. Neurosci. Lett. 267; 81-84.

26. Nishida, T., Arii, T., Takaoka, A., Yoshimura, R. and Endo, Y. (2006) Three-dimensional, computer-tomographic analysis of membrane proteins (TrkA, caveolin, clathrin) in PC12 cells. Acta Histochem. Cytochem. 40; 93-99.

27. Pan, W., Banks, W. A., Fasold, M. B., Bluth, J. and Kastin, A. J. (1998) Transport of brain-derived neurotrophic factor across the blood-brain barrier. Neuropharmacology 37; 1553-1561.

28. Radka, S. F., Holst, P. A., Fritsche, M. and Altar, C. A. (1996) Presence of brain-derived neurotrophic factor in brain and human and rat but not mouse serum detected by a sensitive and specific immunoassay. Brain Res. 709; 122-130.

29. Rose, C. R., Blum, R., Pichler, B., Lepier, A., Kafitz, K. W. and Konnerth, A. (2003) Truncated TrkB-T1 mediates neurotrophinevoked calcium signalling in glia cells. Nature 426; 74-78.

30. Rydén, M. and Ibáñez, C. F. (1996) Binding of neurotrophin-3 to p $75^{\text {LNGFR }}$, TrkA, and TrkB mediated by a single functional epitope distinct from that recognized by TrkC. J. Biol. Chem. 271; 56235627.

31. Sapin, R., Schlienger, J. L., Gasser, F., Pradignac, A. and Grucker, D. (1998) Improved specificity of a new direct assay for urinary cortisol: application in corticoid treated patients. Clin. Chem. Lab. Med. 36; 855-858.
32. Saruta, J., Tsukinoki, K., Sasaguri, K., Ishii, H., Yasuda, M., Osamura, Y. R., Watanabe, Y. and Sato, S. (2005) Expression and localization of chromogranin A gene and protein in human submandibular gland. Cell Tissues Organs 180; 237-244.

33. Saruta, J., Sato, S. and Tsukinoki, K. (2010) The role of neurotrophins related to stress in saliva and salivary glands. Histol. Histopathol. 25; 1317-1330.

34. Saruta, J., Lee, T., Shirasu, M., Takahashi, T., Sato, C., Sato, S. and Tsukinoki, K. (2010) Chronic stress affects the expression of BDNF in rat salivary glands. Stress $13 ; 53-60$.

35. Schober, A., Wolf, N., Huber, K., Hertel, R., Krieglstein, K., Minichiello, L., Kahane, N., Widenfalk, J., Kalcheim, C., Olson, L., Klein, R., Lewin, G. R. and Unsicker, K. (1998) TrkB and neurotrophin-4 are important for development and maintenance of sympathetic preganglionic neurons innervating the adrenal medulla. J. Neurosci. $18 ; 7272-7284$.

36. Schober, A., Wolf, N., Kahane, N., Kalcheim, C., Krieglstein, K. and Unsicker, K. (1999) Expression of neurotrophin receptors trkB and trkC and their ligands in rat adrenal gland and the intermediolateral column of the spinal cord. Cell Tissue Res. 296; 271-279.

37. Siddiqui, M. A., Kashyap, M. P., Khanna, V. K., Yadav, S. and Pant, A. B. (2010) NGF induced differentiated PC12 cells as in vitro tool to study 4-hydroxynonenal induced cellular damage. Toxicol. In Vitro 24; 1681-1688.

38. Szekeres, M., Nádasy, G. L., Turu, G., Süpeki, K., Szidonya, L., Buday, L., Chaplin, T., Clark, A. J. and Hunyady, L. (2010) Angiotensin II-induced expression of brain-derived neurotrophic factor in human and rat adrenocortical cells. Endocrinology 151; $1695-1703$.

39. Tsukinoki, K., Saruta, J., Sasaguri, K., Miyoshi, Y., Jinbu, Y., Kusama, M., Sato, S. and Watanabe, Y. (2006) Immobilization stress induced BDNF in rat submandibular gland. J. Dent. Res. $85 ; 844-848$.

40. Tsukinoki, K., Saruta, J., Muto, N., Sasaguri, K., Sato, S., Tan-Ishii, N. and Watanabe, Y. (2007) Submandibular glands contribute to increases in plasma BDNF levels. J. Dent. Res. 86; 260-264.

41. Yoshizaki, K., Yamamoto, S., Yamada, A., Yuasa, K., Iwamoto, T., Fukumoto, E., Harada, H., Saito, M., Nakasima, A., Nonaka, K., Yamada, Y. and Fukumoto, S. (2008) Neurotrophic factor neurotrophin-4 regulates ameloblastin expression via full-length TrkB. J. Biol. Chem. 283; 3385-3391.

42. Zampieri, N. and Chao, M. V. (2006) Mechanisms of neurotrophin receptor signaling. Biochem. Soc. Trans. 34; 607-611.

This is an open access article distributed under the Creative Commons Attribution License, which permits unrestricted use, distribution, and reproduction in any medium, provided the original work is properly cited. 